\title{
An online survey to explore the awareness and acceptance of geothermal energy among an educated segment of the population in five European and American countries
}

\author{
D. Balzan-Alzate ${ }^{1 *}$ (D) J. López-Sánchez², D. Blessent ${ }^{2}$, J. Raymond ${ }^{3}$, C. Dezayes ${ }^{4}$, J. P. Portela², \\ E. Ramírez Restrepo², D. Moreno Rendón², M. Malo ${ }^{3}$, P. Goderniaux , L. Daniele and T. Le Borgne ${ }^{6}$
}

\section{*Correspondence:}

dbalzan@ing.uchile.cl

${ }^{1}$ Departamento de Geología

Y Centro de Excelencia en

Geotermia de Los Andes

(CEGA), FCFM, Universidad

de Chile, Plaza Ercilla 803,

Santiago, Chile

Full list of author information is available at the end of the article

\begin{abstract}
Advances in new technologies and the desire to achieve a sustainable and safe energy supply, enable communities to transition from conventional to renewable resources, such as geothermal energy. Perception and acceptance amongst different audiences have a high impact on the feasibility of energy projects, which is an important aspect to analyze. For this reason, this study focuses on describing the level of awareness and acceptance of deep geothermal energy within an educated segment of the population in five European and American countries (Canada, Colombia, Chile, Belgium, and France) at different stages of geothermal development. This study was conducted through an online survey, which was targeted to post-secondary students and professionals. Some of the most significant conclusions are: (1) there is a high degree of awareness of geothermal energy among the respondents in Chile and Canada, a medium level in Belgium and France, and a low one in Colombia; (2) there is a favorable acceptance of a geothermal project in each country, even when hydraulic stimulation is considered; (3) environmental aspects and community safety are the most important issues that must be addressed to support a pilot geothermal project.
\end{abstract}

Keywords: Geothermal resources, Awareness, Questionnaire, Renewable energies, Communities

\section{Introduction}

Population increase and industrial growth have generated a worldwide surge in energy demand, which has historically been met by burning fossil fuels, generating greenhouse gas (GHG) emissions, and making their reduction a global challenge (Karmaker et al. 2020). The use of fossil fuels increases the potential for global warming, and the alteration of natural ecosystem processes (Mondani et al. 2017; Amin and Rahman 2019). In the last decade, an increase in the concentration of GHG has been recorded. According to the World Meteorological Organization (WMO), the concentration reached historical values in 2016, with an atmospheric carbon dioxide $\left(\mathrm{CO}_{2}\right)$ concentration growing at a

(c) The Author(s) 2021. This article is licensed under a Creative Commons Attribution 4.0 International License, which permits use, sharing adaptation, distribution and reproduction in any medium or format, as long as you give appropriate credit to the original author(s) and the source, provide a link to the Creative Commons licence, and indicate if changes were made. The images or other third party material in this article are included in the article's Creative Commons licence, unless indicated otherwise in a credit line to the material. If material is not included in the article's Creative Commons licence and your intended use is not permitted by statutory regulation or exceeds the permitted use, you will need to obtain permission directly from the copyright holder. To view a copy of this licence, visit http://creativeco mmons.org/licenses/by/4.0/. 
record speed, showing the highest values in recent years (WMO 2019). The large emissions of GHG, especially $\mathrm{CO}_{2}$, produced by anthropogenic activities and their influence on climate conditions have become a major ecological and political challenge (Mondani et al. 2017). One of the goals detailed in the United Nations Organization 2030 agenda is to guarantee access to affordable, safe, sustainable and modern energy for all, in addition to the adoption of measures to fight climate change and its effects (UN 2015). Renewable energies are an efficient and effective solution (Dincer 2000). They are considered a promising and clean alternative worldwide, as they are produced from natural, nondepleting sources, such as sun, wind, waves, water and Earth's heat (Wüstenhagen et al. 2007; Lins et al. 2014; Owusu and Asumadu-Sarkodie 2016).

Among the renewable energies, one of the most sustainable options is geothermal energy (Dincer and Acar 2015). According to IPCC (2012), the global technical potential for electricity generation by means of geothermal energy is estimated at $200 \mathrm{GW}$. The geothermal capacity installed worldwide in 2018 was $13.33 \mathrm{GW}$, of which $1.65 \mathrm{GW}$ were in Latin America (Mexico, Guatemala, El Salvador, Nicaragua, Costa Rica, Honduras, and Chile), $2.55 \mathrm{GW}$ in United States, 2.96 GW in Europe, 4.44 GW in Asia, and 0.67 GW in Africa, and 1.05 in Oceania (IRENA 2019). Goldstein et al. (2012) estimated that future geothermal deployment can meet between 2.5 and $4.1 \%$ of the global electricity demand, and about $5 \%$ of heating and cooling needs by 2050 . Use of deep geothermal energy sources was initially limited to specific areas with favorable conditions: having a heat source, a recharge mechanism, and an accessible depth, among others (DiPippo 2012). Technological advances such as EGS facilitate the use of geothermal energy in areas where these conditions are not met. The use of hydraulic stimulation, one of EGS's existing techniques in addition to chemical and thermal stimulations (Watanabe 2016), to improve the permeability of geothermal reservoirs began with the Hot Dry Rock concept put forward at Los Alamos (New Mexico, USA) in the 1970s (Olasolo et al. 2016). Dickson et al. (2004) additionally indicated that the direct use of heat is possible with the implementation of techniques to ensure permeability and circulation of fluids. EGS is projected to be an important technology to the global growth of geothermal energy. The International Energy Agency (IEA) forecasted a global geothermal production of 140$160 \mathrm{GW}$ in 2050, with a $60 \%$ share provided by EGS (IEA 2011). Such systems have been studied with field experiments throughout the world in different geological environments (Palacio-Villa et al. 2020), for example, the Fenton Hill project in the United States (Reiter et al. 1976), Soultz-sous-Forêts in France (Cuenot et al. 2008), Basel in Switzerland (Wyss and Rybach 2010), Groß Schönebeck in Germany (Huenges et al. 2006), Paralana in Australia (King et al. 2009), Ogachi in Japan (Kaieda and Ogachi 2012).

Although geothermal energy is seen as a promising source of renewable energy, its development is constrained by several challenges, most notably social resistance (Bertani 2016). Acceptance problems in different social sectors, lack of knowledge and negative perceptions can affect the development of energy technologies (Dowd et al. 2011). However, considering the local community as an obstacle to be overcome may not provide an adequate basis for building trust. In this sense, developers or promoters of geothermal projects should generate a relationship with stakeholders that is not one-way (Vargas et al. 2020). 
It is important to understand that technology, society, and governance are interrelated, since a change in one is likely to affect the others. Therefore, their interdependencies impact the acceptance of change and technology by society, an aspect that plays an important role in the evolution of new energy developments. As expressed by Jasanoff (2004), the relationship between science and technology has a common value, i.e., science generates an impact on society and society impacts science. Entrepreneurs, scientists, and policymakers working in the field of new energy technologies are constantly finding new reasons to involve the public in innovation (Jugend et al. 2020). Energy research should focus on problem-oriented, interdisciplinary, and socially inclusive studies (Sovacool et al. 2015; Lennon et al. 2019).

Citizen participation can help to prevent, or at least anticipate, possible future controversies, to provide ideas for new and better products and services, and to increase the openness and transparency of scientific and technological developments, which is a prerequisite for a trust relationship between different actors (Meller et al. 2018). Involvement of citizens has also demonstrated that they can be proactive and come up with interesting suggestions, such as including energy and environmental issues in educational programs, from elementary school to universities (Pellizzone et al. 2015). One tool that enables the connection between different actors involved in the development of a project is the communication of the environmental issues and energy technologies that shape public opinion, change policies, and affect our world (Dowd et al. 2011).

Implementing appropriate communication strategies on energy transition projects, such as geothermal energy, can have a positive or sometimes negative impact on the way those projects are understood and accepted or not. It is important to communicate technical and scientific content in an effective way, making the relevant information as easy to understand as possible. Moreover, the proper time should also be selected: communication strategies must be implemented before starting any kind of energy development. For example, Volken et al. (2018) identify that in the communication processes on new technologies, acceptance can increase or decrease: in Switzerland, geothermal energy acceptance decreased with increasing knowledge, probably upon learning about accidental impacts, such as induced seismicity that occurred in the past (Häring et al. 2008).

In contrast, the study presented by Carr-Cornish and Romanach (2014) shows a positive change in perception when participants acquired information and knowledge on the subject, noting that the change in attitude is evident even when it comes to concerns related to groundwater pollution or induced seismicity. The study by Pellizzone et al. (2017) conducted in Viterbo, Italy, revealed that the perception of renewable energies including geothermal energy is positive and optimistic, but, like Carr-Cornish and Romanach (2014), indicated that when the construction of a geothermal project is considered in the immediate environment, the favorable perception of the affected population decreases, giving rise to the phenomenon known as "Not in my backyard". Acceptance is complex and varies according to the proximity of the geothermal power plant to the communities, which is identified as a relevant factor to be considered from the early stages of any project. Thus, acceptance represents an important value in the implementation of new technologies such as geothermal energy. In fact, in seven European countries (Hungary, Italy, Macedonia, Poland, Romania, Serbia, and Slovakia), 
geothermal resources have been exploited below their real potential due to a low or total lack of public acceptance, among other reasons (Kępińska and Kasztelewicz 2015).

The discussion of geothermal projects in different social sectors is generally based on environmental, economic, and political aspects (Meller et al. 2018). Moreover, the media have also a crucial role on this discussion, depending on how they present deep geothermal energy to the public, as analyzed by Stauffacher et al. (2015), who highlighted the requirement of transparency and diligent monitoring of communication and public engagement. There are multiple factors that affect opinion on geothermal energy, such as contamination of groundwater, sustainability of water resources, uncertainty on reversibility, seismic activity, cost-benefit ratio, level of knowledge about the technologies, dissemination channels, the integration of various actors in project planning and public consultation exercises, among others (Dowd et al. 2011; Carr-Cornish and Romanach. 2014; Chavot et al. 2018).

In this context, through the research project IGCP636Y "Unifying international research forces to unlock and strengthen geothermal exploitation of the Americas and Europe" of the UNESCO's International Geoscience Program (IGCP), an online survey was conducted to explore the perception of geothermal energy among people with a scientific background and high education level in Canada, Colombia, Chile, France, and Belgium (the five countries leading the IGCP636Y project). The International Geoscience Programme (IGCP) started in 1972 and fosters international scientific cooperation in geosciences. Among other aspects, its mission includes promoting sustainable use of natural resources, such as hot deep fluids and heat stored in the subsurface which provide geothermal energy. IGCP projects focus on global issues of geosciences within these five themes: Earth Resources, Global Change, Geohazards, Hydrogeology, and Geodynamic. The project IGCP636 belongs to the first topic, and it is currently on its second phase 2020-2025. The objective of this survey was to explore and describe the general attitude toward geothermal energy of the participants. This survey represents the first stage of a future analysis that can involve different sectors of society, and thus describe and explore the social acceptance of geothermal energy in different countries. The relevant results obtained from this survey are discussed in this paper.

\section{Overview of geothermal resources in the surveyed countries}

A short overview of geothermal resource characterization and potential is provided in the following sections for each country included in the survey. To better understand the results of the public survey, a state of geothermal development was assigned to each country studied. Early (exploration activities), moderate (some geothermal heat and/or power plants in operation or demonstration projects) and advanced (several commercial heat or power plants) development statuses are the proposed categories to classify the development in each country.

Considering the current context of the geothermal industry and/or exploration studies conducted in each country, as detailed in the following sections, an advanced level of development is assigned to France, moderate to Belgium, Canada, and Chile, while an early development is appointed to Colombia. These countries are therefore case studies that are representative of all development stages, giving a complete 
overview of geothermal development in different situations across Latin America, North America, and Europe.

\section{Canada}

Geothermal energy in Canada is used primarily for heating and cooling purposes, with over 103,523 geothermal heat pump systems having shallow ground heat exchangers installed across the country, totaling an estimated $1449 \mathrm{MW}$ of heating capacity and 11,111 TJ of annual energy use (Raymond et al. 2015). However, there is currently no commercial exploitation of deep geothermal resources for electricity production. Exploration of deep geothermal resources has been conducted since 1973, with the identification of several strategic points, including the Meager Creek geothermal area, $160 \mathrm{~km}$ north of Vancouver, where deep wells were drilled during the 1980s for the purpose of carrying out tests (Jessop et al. 1991). New geothermal exploration projects are now ongoing in sedimentary basins, for example targeting deep resources in Saskatchewan. The state of deep geothermal development in Canada can be classified as moderate, where activities are mainly focused on deep resource evaluation and drilling for exploration purposes. The estimated maximum energy potential for the most promising geothermal resources in the deepest parts of the Canadian basins is $150 \mathrm{~kJ} / \mathrm{kg}$ (Majorowicz and Grasby 2019). Although the deep geothermal industry is not mature, it shows a promising outlook.

\section{Colombia}

The studies of geothermal resources in Colombia began in the 1970s (Arango et al. 1970). However, geothermal exploitation has not yet been developed since Colombia has limited technical and scientific capacity for the development of geothermal resources and the areas of interest are located in isolated volcanic zones (Mejia et al. 2014). The only geothermal exploration well in Colombia (Nereidas 1) was drilled in 1997 on the western flank of the Nevado del Ruiz Volcano, and could not reach the predicted depth of $2000 \mathrm{~m}$ because it suffered a strong deviation (Monsalve et al. 1998). Colombia has a great potential for the exploitation of geothermal energy, thanks to its strategic location within the fire belt, which allows different thermal manifestations to be seen throughout the country (Moreno-Rendón et al. 2018). Projections indicate that the geothermal potential on the Nevado del Ruiz volcanic complex is $50 \mathrm{MW}$. In addition, the binational geothermal project Tufiño-ChilesCerro Negro that is being developed on the borders of Colombia and Ecuador presents an estimated potential of $138 \mathrm{MW}$ (Mejia et al. 2014), which is evidence of the geothermal potential of the country. Colombia can therefore by characterized as an early development stage country, since only exploration studies have been conducted (Alfaro 2015) and knowledge and expertise are still limited. Nevertheless, the national development plan 2018-2022 mentions the introduction of a geothermal regulation framework and all the actors involved in its creation (Colombian National Planning Department 2019), opening doors to the development of this type of resource. 
Chile

Chile's geothermal exploration started between 1921 and 1922 with exploration campaigns led by Larderello's Italian technical team, which drilled two wells, one $70 \mathrm{~m}$ deep and the other 80, in the Antofagasta region (Lahsen et al. 2015). Exploration of geothermal resources was subsequently suspended until 1968. Between 1968 and 1976, geological, geochemical, and geophysical information were collected in the Surire, Puchuldiza, and El Taito geothermal fields (Procesi 2014). In addition, exploratory wells were drilled to evaluate the feasibility of the areas for electric energy production (Morata 2004). The geothermal potential that can be exploited in the country is approximately $2100 \mathrm{MW}$ for the 2017-2050 period, with $600 \mathrm{MW}$ in 2017-2030 and $1500 \mathrm{MW}$ in the following period of 2031-2050 (Chilean Ministry of Energy 2018). Enel Green Power together with the National Petroleum Company built the first geothermal plant called Cerro Pabellón with a capacity of $48 \mathrm{MW}$ distributed in two units (Jorquera 2017). In 2016, a national survey about energy was conducted in Chile (Chilean Department of Energy 2017) and the results indicate that around 30\% of the Chilean population knows about geothermal energy as a source of electricity; moreover, among those who are aware of this type of energy, $70 \%$ agree with the construction of geothermal power plants. Chile is then considered at a moderate geothermal development stage.

\section{Belgium}

The first well for geothermal exploration in Belgium was drilled in 1975 (Hoes et al. 2013). The current geothermal exploitation in the Mons area is entirely dedicated to heat production and district heating. With a temperature of approximately $70{ }^{\circ} \mathrm{C}$, three pumping wells provide heating energy to hospitals, public buildings and businesses. In 2017, the installed capacity was 8.1 MW. The use of geothermal energy in the Mons region is expected to increase in the coming years (Scharff 2019). Several wells were exploited in the chalk reservoir of Flanders, for heating swimming pools and fish farming, but these operations have been stopped. Another project is currently being completed in the north, near the city of Antwerp (Richter 2018). The Balmatt project is the first experience of deep geothermal energy production in Belgium combined with heat generation. The research organization VITO is building the Balmatt heating plant; three deep wells have been drilled between 2016 and 2018 and to improve the understanding of the reservoir, a more detailed analysis was started, using data gathered from those three wells (Lagrou et al. 2019). A faulted area in the Campine Dinantian limestone deposit is the target at a depth of $2.8-3.8 \mathrm{~km}$ (Loveless et al. 2014). Belgium can be considered to be at a moderate geothermal development stage.

\section{France}

Geothermal development in France is expected to grow using ground source heat pumps as well as geothermal district heating, with an estimated installed thermal capacity of $345 \mathrm{MWt}$ (Vernier et al. 2015). France is one of the leading European countries in geothermal district heating. French power plants are located in Guadeloupe and in Alsace, at Soultz-sous-forêts. The power plant Bouillante, in Guadeloupe, consists of two units: a double-flash unit operating since 1986 and a single-flash unit inaugurated in 2004. They produce $15 \mathrm{MW}$, which represents about $5 \%$ of the island's electricity supply 
(Bouchot et al. 2010). The power plant has the potential to be expanded by $30 \mathrm{MW}$ for a total capacity of 45 MW by 2021 (Richter 2016). The Soultz EGS pilot plant in northeastern France has been connected to the grid since the beginning of 2011. This plant, which is part of an innovative European research program based on EGS technology, was initiated in 1987 by the Bureau de Recherches Géologiques et Minières (Genter 1990). Moreover, the geothermal heat plant in Rittershoffen inaugurated in 2017 is the first geothermal heat plant worldwide for industrial uses. It is a model for the energy transition, and together with the EGS power project in Soultz-sous-Forêts, it demonstrates that deep geothermal energy can be developed almost anywhere, powering and heating a cleaner, more sustainable Europe (Mouchot et al. 2018). France can be considered to be at a high geothermal development stage.

\section{Research methods}

In the framework of the IGCP636Y UNESCO project led by the University of Medellin (Colombia), and in collaboration with the Institut national de la recherche scientifique (INRS) (Canada), Andean Geothermal Center of Excellence (CEGA) (Chile), Université de Mons (Belgium), Université de Rennes (France), and Bureau de Recherches Géologiques et Minières (BRGM) (France), a survey of 15 questions was conducted, with six of them discussed below. The remaining nine questions were related to general topics associated with other renewable energies, and not specifically to geothermal energy, which is why they are not presented here. The countries chosen are a function of the project collaborators. The survey aimed to explore the opinion of the respondents on deep geothermal energy and its possible development, including the eventual use of hydraulic stimulation as a feasibility mechanism.

\section{Questionnaire design}

The survey was available in English, Spanish, Dutch, and French, with a qualitative approach, and formulation to accommodate the respondent's desire to answer or not, including the option to select "I do not know-I prefer not to answer". Two descriptive texts were provided as background information to answer two of the six questions discussed in the article (Additional file 1: Appendix A). The first text was used to support the question: "What is your opinion of the use of geothermal energy for electricity production in your country?". Deep (high enthalpy) and shallow geothermal energy (low enthalpy) were differentiated in this first text. The second text was used to explain that hydraulic stimulation is sometime required in geothermal projects to improve the permeability of the rock and thus increase the feasibility of a project for electricity generation. The following question was asked: "If hydraulic stimulation is required, what is your acceptance of the development of a pilot geothermal energy project in your country?". The texts were designed in a clear and simple way so that technical details or words used did not influence the answers of the respondents (Additional file 1: Appendix A).

\section{Data collection}

The survey was built on the QuestionPro platform and shared through emails, social media, dissemination at geothermal conferences, bulletins from the CEGA in Chile and BRGM in France. The respondents were mainly people having a high level of education, 
with a completed or ongoing university education. Because of the methods used to share the survey, it is likely that a part of the respondents has a background in engineering and/or geoscience fields, or is somewhat familiar with those areas, which facilitates their understanding of the survey. This part of the population is relevant, regardless of whether it is representative or not to the views of the general public, since it is the group of the professional stakeholders, according to Fung (2006). Sharing the survey online was the best option to achieve the goal of this study with the available project resources, although some segments of the population could not be represented among the respondents. This survey has therefore been considered an exercise to establish the basis for a future survey that can evaluate the social perception in each of the countries, with responses representative of the whole society.

This survey was based on a previous study conducted by Malo et al. (2015) in the province of Quebec (Canada) and the main differences were: (1) the translation to different languages, since the survey conducted in Quebec was done in English and French; (2) the dissemination method, since the survey conducted by Malo et al (2015) was coordinated by a professional company, Leger, a Canadian Institute specialized in surveys; (3) the coverage, since the work conducted by Malo et al. (2015) presented a local approach (Quebec province). The survey conducted in Quebec was designed by the market research and analytics Canadian company Leger that pre-tested the questionnaire with a selected number of respondents to ensure its internal logic and smooth operation. The analysis described here is therefore based on a well-founded structure and well-designed survey. The average time required to complete the survey was $9 \mathrm{~min}$.

\section{Sample}

The survey was distributed at the end of 2016 for approximately 4 months. The responses received were filtered to consider only those that were given by people enrolled in a university program or that already completed it, in order to select the same segment of population in each country. In total, 1063 responses have been therefore considered for the analysis described here and they are distributed as follows: Belgium 150, Canada 258, Colombia 249, Chile 193, and France 213. All the results analyzed here are related to multiple-choice questions. Demographic information was queried at the beginning of the survey to verify the respondents' fit into the segment of population considered in this study, based on the highest education program in progress or completed by the respondent. To check if the responses to the survey were statically representative of the population in each country in terms of gender, one question about gender was included in the survey. In general, the sample reflects more or less the distribution in the population of each country (Table 1). In terms of age, the most represented range is $31-50$ years for Canada, Belgium, and France, while it is $17-30$ years, for Colombia and Chile.

Additionally, the age ranges of respondents are shown in Table 2.

\section{Results}

The answers to the questions of the survey analyzed here are presented in this section. The results on the acceptance of deep geothermal energy to generate electricity, with and without hydraulic stimulation, are presented together to compare how the acceptance percentage changes if EGS technology is considered (Table 3). 
Table 1 Percentage distribution of respondents by gender

\begin{tabular}{|c|c|c|c|c|c|c|c|c|c|c|}
\hline & \multicolumn{10}{|c|}{ Percentage distribution by gender } \\
\hline & \multicolumn{2}{|l|}{ Canada } & \multicolumn{2}{|c|}{ Colombia } & \multicolumn{2}{|l|}{ Chile } & \multicolumn{2}{|l|}{ Belgium } & \multicolumn{2}{|l|}{ France } \\
\hline & Female & Male & Female & Male & Female & Male & Female & Male & Female & Male \\
\hline Whole country & 50.3 & 49.7 & 50.9 & 49.1 & 50.8 & 49.2 & 50.7 & 49.3 & 51.7 & 48.3 \\
\hline Respondents to this survey & 46.6 & 53.4 & 50.7 & 49.3 & 56 & 44 & 45.3 & 54.7 & 43.2 & 56.8 \\
\hline
\end{tabular}

Table 2 Percentage distribution of respondents by age

\begin{tabular}{lll}
\hline & Age & Percentage \\
\hline Colombia & $17-30$ & 49.5 \\
& $31-50$ & 37.3 \\
Chile & $51-80$ & 13.2 \\
& $17-30$ & 55.8 \\
& $31-50$ & 33.9 \\
Canada & $51-80$ & 10.3 \\
& $17-30$ & 25.4 \\
Belgium & $31-50$ & 55.1 \\
& $51-80$ & 19.5 \\
France & $17-30$ & 33.7 \\
& $31-50$ & 44.9 \\
& $51-80$ & 21.5 \\
& $17-30$ & 21.2 \\
\hline
\end{tabular}

Table 3 Acceptance of geothermal energy for electricity generation, with and without hydraulic stimulation

\begin{tabular}{|c|c|c|c|c|c|}
\hline & & & $\begin{array}{l}\text { Strongly agree } \\
\text { and Somewhat } \\
\text { agree }\end{array}$ & $\begin{array}{l}\text { Strongly disagree } \\
\text { and Somewhat } \\
\text { disagree }\end{array}$ & $\begin{array}{l}\text { I do not know/l } \\
\text { prefer } \\
\text { not to answer }\end{array}$ \\
\hline \multirow[t]{5}{*}{1} & \multirow{5}{*}{$\begin{array}{l}\text { Acceptance of deep geo- } \\
\text { thermal energy to gener- } \\
\text { ate electricity (without } \\
\text { mentioning hydraulic } \\
\text { stimulation) }\end{array}$} & Belgium & 79.49 & 12.82 & 7.69 \\
\hline & & Canada & 84.81 & 11.48 & 3.70 \\
\hline & & Colombia & 84.72 & 11.35 & 3.93 \\
\hline & & Chile & 96.46 & 2.53 & 1.01 \\
\hline & & France & 78.34 & 15.21 & 6.45 \\
\hline \multirow[t]{10}{*}{2} & \multirow{5}{*}{$\begin{array}{l}\text { Acceptance of deep geo- } \\
\text { thermal energy consider- } \\
\text { ing, eventually, the use } \\
\text { of hydraulic stimulation }\end{array}$} & Belgium & 62.82 & 22.44 & 14.74 \\
\hline & & Canada & 77.41 & 15.56 & 7.04 \\
\hline & & Colombia & 69.43 & 25.76 & 4.80 \\
\hline & & Chile & 86.87 & 10.61 & 2.53 \\
\hline & & France & 60.37 & 28.11 & 11.52 \\
\hline & \multirow[t]{5}{*}{$\%$ difference $2-1$} & Belgium & -16.67 & 9.62 & 7.05 \\
\hline & & Canada & -7.41 & 4.07 & 3.33 \\
\hline & & Colombia & -15.28 & 14.41 & 0.87 \\
\hline & & Chile & -9.60 & 8.08 & 1.52 \\
\hline & & France & -17.97 & 12.90 & 5.07 \\
\hline
\end{tabular}




\section{Description of main issues related with energy production}

As a result of the question "What are the main issues related to energy production in your region?", environmental impacts and the development of renewable energies appear to be the main concern in each of the countries surveyed, except for Chile, where respondents attribute the type of resource used as the second most important aspect (Fig. 1). The type of resource used to produce energy and the cost of energy production are the third and fourth topics selected for Canada, Colombia, Belgium, and France, while achieving energy diversification, energy supply and energy independence appear to be of lesser importance among the respondents.

\section{Self-assessed level of knowledge}

Based on a self-assessment, respondents expressed their level of knowledge about geothermal energy. Figure 2 shows the results obtained from the population surveyed starting from a qualitative scale that gradually increases from "Never heard" to "Very well", with the option of answering the question or not. The results show that for the respondents in Chile and Canada there is high knowledge with 79 and 64\%, respectively, for the answers "Well" and "Very well". France with $49 \%$ and Belgium with $44 \%$ present greater knowledge than Colombia with $35 \%$, but less than Chile and Canada. It is important to note that, except for Colombia with $9 \%$, only less than $3 \%$ of respondents indicated they have never heard about geothermal energy. These results show that the respondents in Chile and Canada are very familiar with geothermal energy, while in France and Belgium they have an average knowledge and in Colombia a low level of knowledge.

\section{Acceptance of geothermal energy production}

In relation to the acceptance of geothermal energy production, respondents were asked on a qualitative scale from "Strongly disagree" to "Strongly agree", with the option of

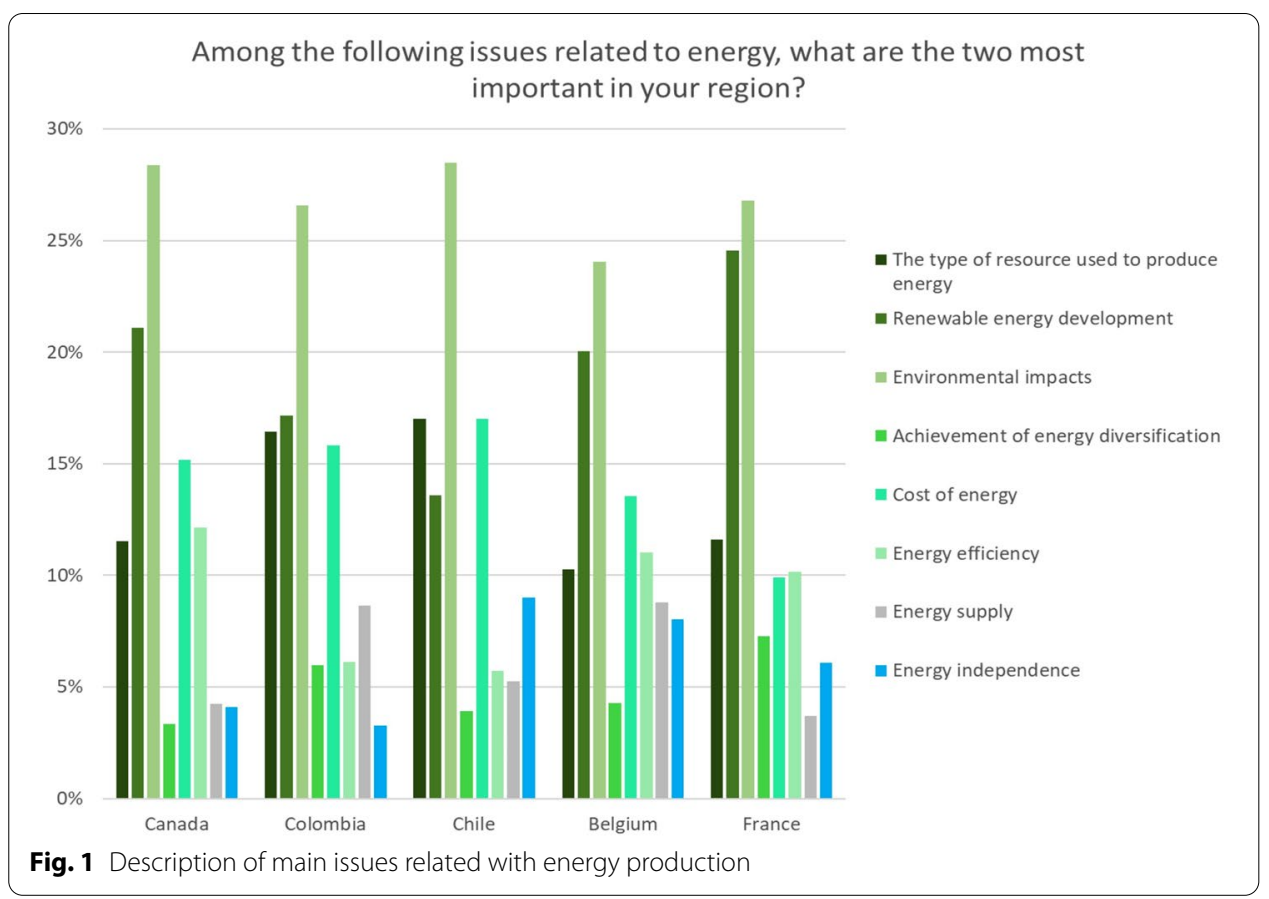



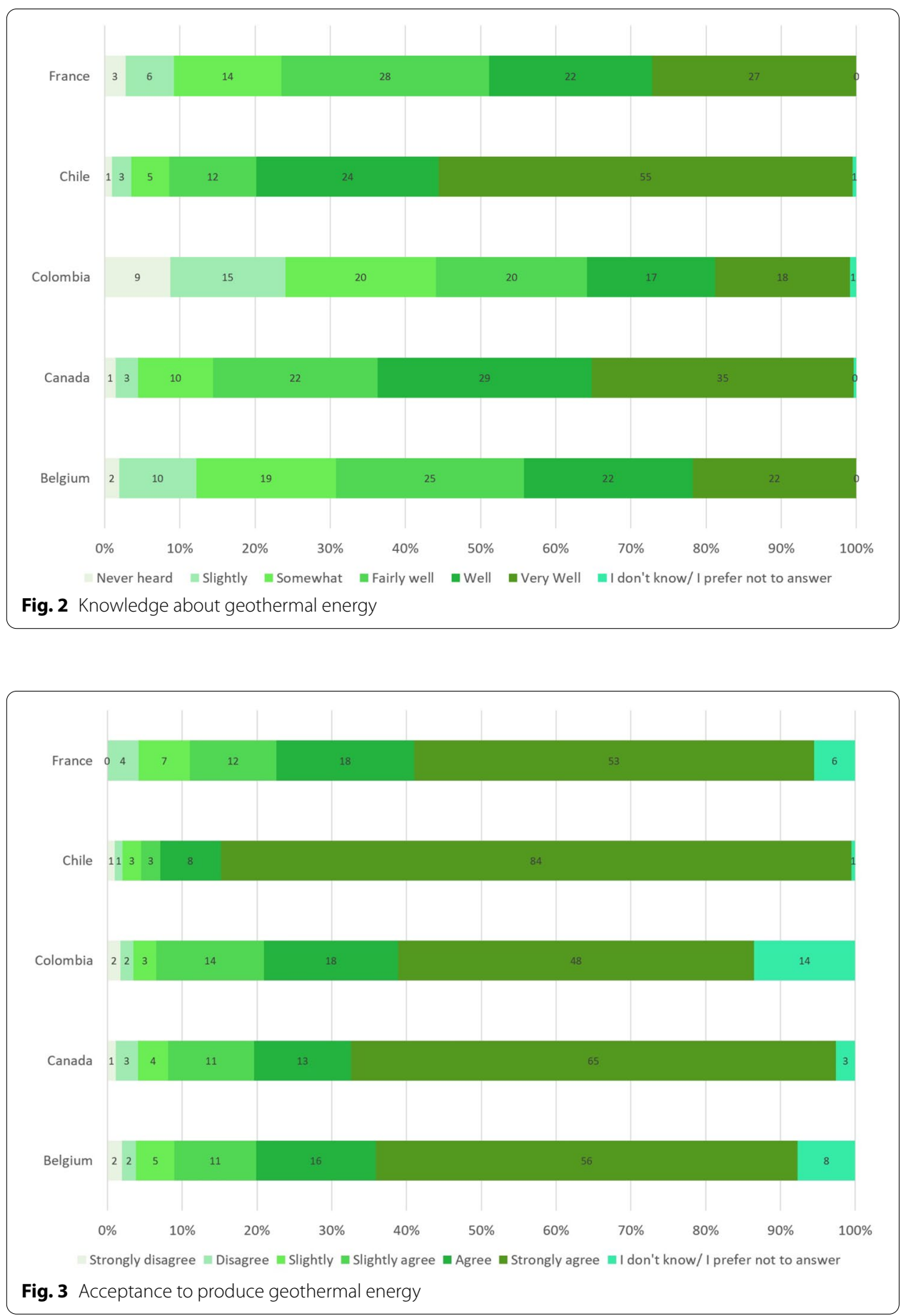

answering "I don't know/I prefer not to answer", about their level of acceptance of geothermal energy production in their country. It is shown that the respondents in each country indicated a high level of acceptance for "Strongly agree" and "Agree", where Chile shows a higher level of acceptance compared to the other countries with a percentage between "Strongly agree" and "Agree" of 92\%, followed by Canada with 78\% and France, Belgium and Colombia with 71, 72, and 66\%, respectively (Fig. 3). 
Acceptance of deep geothermal energy to generate electricity, with and without hydraulic stimulation

Questions with respect to this subject were accompanied with an explanatory text (Additional file 1: Appendix A). The focus of the questions was to explore the acceptance of a geothermal project for electricity generation, with and without the use of hydraulic stimulation. After the first explanatory text about the difference of geothermal energy for electricity generation and heating production, the respondents show high acceptance, with a minimum value of $79.49 \%$ for Belgium and a maximum of $96.46 \%$ for Chile. After the description of hydraulic stimulation applied to geothermal reservoirs, a decrease in the acceptance was observed, with a maximum reduction for France of $17.97 \%$ and minimum for Canada of $7.41 \%$. It is also important to mention that the respondents showed insecurity with respect to the implementation of geothermal energy requiring hydraulic stimulation, but they are not inclined to accept or deny its acceptance, that is, impartiality increases (Table 3).

\section{Conditions that should be satisfied to support a geothermal pilot project}

Figure 4 shows the conditions that must be met to improve acceptance of geothermal pilot projects. A pilot project is an initial small-scale implementation to prove viability of a larger deployment. In the context of power generation, pilot-scale projects are demonstrating technologies that use specific sources to provide safe and reliable operation of the plant, engineering data, and confidence in the design and construction of future installations. Pilot plants may become commercial-scale power operations at particularly favorable locations (National Research Council 2010). Among the most important issues identified are guarantees for the conservation of the landscape and protection of the environment, guarantees in terms of the safety of personnel and of the communities close to the plant, and information and consultation with the community on the

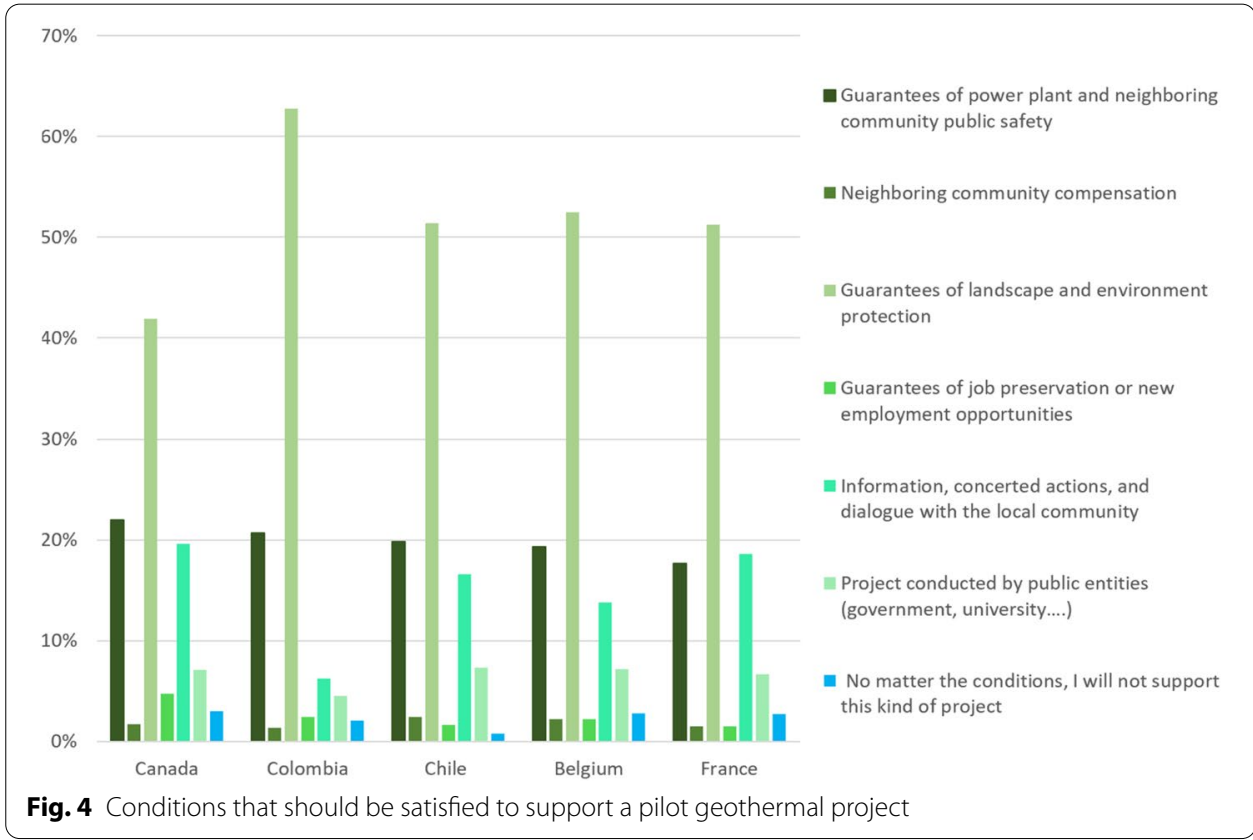


activities carried out in the territory. It is important to bear in mind that the least importance was given to financial compensation to the community and to guarantees for the preservation of employment or for new employment opportunities.

\section{Discussion}

The respondents were asked to self-assess their degree of awareness about geothermal energy and to express their opinion and perception about energetic issues, acceptance of geothermal energy for electricity production, and implementation of a pilot project with and without the use of hydraulic stimulation. The selected segment of population has, in general, a medium/high awareness about geothermal energy. Therefore, this exercise indicates that outreach activities should address the remaining segments of the population. In the following subsections, each topic is separately discussed, following the same order used to describe the results in the previous section: (1) issues related with energy production; (2) self-assessed level of knowledge; (3) acceptance of geothermal energy production; (4) impact of hydraulic stimulation, and (5) conditions that should be satisfied to support a pilot geothermal project.

The highlights of this study can be summarized as follows: (1) this exercise provides the first attempt to explore the geothermal perception of a segment of population in countries belonging to different development categories; (2) in general, highly educated people have a medium/high knowledge of geothermal energy and may contribute to develop knowledge-sharing mechanisms throughout the whole society, and (3) outreach activities that should be implemented to foster geothermal development have to address specific segments of population.

In the analyzed countries highly educated people show higher awareness about geothermal energy than what is indicated by studies that are representative of the whole population (Carr-Cornish and Romanach 2014; Pellizzone et al. 2017). Likewise, in the five countries there is a growing interest in promoting the use of geothermal resources, such that joint studies are useful to share experience and policies.

The main differences are associated with the local economic, social, politic, and energy background. In the literature, there are no publicly available studies that compare the perception of geothermal energy in areas belonging to different development conditions as done here, with countries from Europe, North and South America. However, it would be hard to quantitatively compare the answers to this survey if the respondents lived in completely different scenarios. In addition, the development of a geothermal project is site-specific and must be adjusted to the needs of local stakeholders (Benighaus and Bleicher 2019). Furthermore, it can have an opposite outcome within the same country, as shown by Yasukawa et al. (2018) in Japan. Therefore, this study focuses on a qualitative analysis of similarities and differences that provides an interesting insight into geothermal perception for a specific segment of the population.

\section{Description of main issues related with energy production}

Energy is seen as a critical factor in providing prosperity for a modern society, but, on the other hand, is a potential source of environmental damage (Wadström et al. 2019). Therefore, there is a close relationship between the production of electricity and environmental impacts, which is determined by sources used for its production. Sources of 
electrical energy such as fossil fuels, water resources and nuclear fuel are associated with an environmental cost, such as GHG emissions, rigorous procedures for long-term storage of nuclear waste or degradation of aquatic ecosystems. These factors, together with the high dependence of Chile on fossil fuels (O'Ryan et al. 2020), of Colombia and Canada on hydroelectric energy (Gómez and Navarro 2018; CER 2020), and of France and Belgium on nuclear energy, make up a critical panorama in environmental aspects and explain the strong concern of respondents about the environmental impacts associated with electricity production. Along the same line, the future development of renewable energies, which are presented as a tool to fight the main environmental aspects associated with electricity production (Owusu and Asumadu-Sarkodie 2016), is the second most important issue identified in the results (Fig. 1).

The results obtained can also be interpreted considering the specific context of some of the countries. In Chile, there was a serious electricity crisis that required rationing in 1998 and 1999, and subsequently, there was a significant increase in the cost of power generation in 2007 and 2008, which showed that Chilean installed capacity was not sufficient and that the entire energy system was weak, since it depended mainly on imports. Looking at the "Achievement of energy diversification" response option, France has the highest percentage (7.5\%), among all the countries analyzed, perhaps because nuclear energy in 2015 represented $78 \%$ of electricity generation, the highest share worldwide (IEA 2017), indicating that people would like to switch to other kind of energy sources, considering all the issues related with nuclear power generation. Energy efficiency, supply, and independence can be analyzed together in Belgium. The obtained responses can be affected by the risk of electricity shortage experienced during the winters preceding this survey and explained by technical problems and the temporary closure of some nuclear power plants. This feeling can be exacerbated by the government decision to close all nuclear power plants by 2025 (IEA 2016), affecting the energy matrix of the country, where $49.9 \%$ of the energy, in 2017, came from nuclear power (FEBEG 2020). If nuclear power plants are closed by 2025, there will be an impact on the economy: energy imports will be required, and cost will be affected. Therefore, this can explain why respondents are interested in the issue of energy independence.

In addition, it is important to highlight that the cost of energy is one of the main issues raised in these countries. It can be related to the need to develop renewable energies, since they should have a lower end-user cost than conventional fossil fuels-based energy, as demonstrated by the ongoing competitiveness of the mature renewable power generation technologies-hydropower, bioenergy and geothermal, together with a continued improvement in the competitiveness of solar and wind power technologies (IRENA 2020).

\section{Self-assessed level of knowledge}

The level of knowledge of geothermal energy is addressed here from a general viewpoint, considering both low and high enthalpy systems. Therefore, the results to this question are described from a general perspective. Although there is a limited overall understanding associated with geothermal energy for general public (Cataldi 1999), Fig. 2 shows a medium-high level of knowledge, except for Colombia, where a lower level of knowledge is shown. 
In Chile, a study conducted by Vargas (2018) about a community near the Villarrica volcano in the Araucanía region suggests that there is a low level of understanding of the technology involved in geothermal energy production. At the same time, the Chilean national survey conducted in 2016, indicates that around the $30 \%$ of Chilean population is aware of geothermal energy as a source of electricity (Chilean Department of Energy 2017).

In Canada, Malo et al. (2015) indicated that the population in the Quebec province has a low level of knowledge about surface and deep geothermal energy.

The panorama in Europe is not different to what is happening in Canada, Chile, and Colombia with respect to the level of knowledge: according to the European Geothermal Energy Council (Reith et al. 2013), the levels of information and awareness about the different technologies, in particular geothermal energy, can be qualified as low.

Colombia presents the lowest knowledge, which may be related to the level of early geothermal development. It is important to note that the Colombian Association of Geothermal Energy (AGEOCOL) has created different events to disseminate information on geothermal energy, which began in December 2016 with the first national geothermal energy meeting (RENAG) held in Bogotá, just after the implementation of this survey. This could explain the low degree of awareness about geothermal energy recorded.

The results of this survey contrast with the general level of knowledge indicated by the studies mentioned here, except from Colombia. The results strictly apply to a specific group of the population, mainly constituted by persons with post-secondary education.

\section{Acceptance of geothermal energy production}

The level of knowledge of a given technology is not necessarily proportional to its acceptance. Therefore, a question was established to better explore the acceptance of geothermal energy production. This is based on the concept that the social acceptance of geothermal development is not simple (Allansdottir et al. 2019). The results of the question indicate (as presented in the section "Description of main issues related with energy production") that the acceptance of geothermal energy by people who completed the survey is high for all countries, even though the acceptance of a technology is not easy to address from a social perspective. The moderate-high acceptance shown by the respondents may also be associated to the general awareness of global warming and climate change, as well as the importance of a diversified energy matrix, which are topics frequently mentioned in the news and scientific community. It seems that an intuitive or technical knowledge of general or specific aspects of geothermal energy allows people to associate geothermal systems as a technology that opens the door to the energy transition. However, this result is specific for this type of population and it should not be generalized. In fact, there is limited evidence that more informed individuals show higher acceptance of low carbon technologies, and in some cases the effect can even be the opposite (Volken et al. 2018; Dubois et al. 2020). Although some studied indicated a correlation between knowledge and acceptance, others reveal that the levels of support were independent of levels of awareness (Devine-Wright 2007). Moreover, acceptance varies for each specific project and area of implementation, but a good public information campaign can help communities to correctly understand the different challenges of the project (Colla et al. 2020). In general, the acceptance of new energy technologies 
has been investigated by different scientific disciplines, but a coherent overview is still missing (von Wirth et al. 2018). It is therefore worth conducting specific case studies, such the survey described here focused on geothermal energy, to increase the range of available experiences that can be analyzed and compared to foster the development of renewable energies.

\section{Acceptance of deep geothermal energy to generate electricity, with and without hydraulic stimulation}

The question about the acceptance of geothermal energy for electricity generation, indicating a maximum value for Chile with $96.46 \%$ and a minimum for Belgium with $79.49 \%$, showed the consistency of the respondents with the answers presented in the previous sections. In contrast, in Chile, the national survey conducted in 2016 and covering all population segments indicated a lower acceptance (Chilean Department of Energy 2017), confirming that the acceptance varies with the population segment investigated. When evaluating geothermal electricity production with hydraulic stimulation, the results showed a decrease in all countries, with a maximum decrease of $17.97 \%$ for France and a minimum of $7.41 \%$ for Canada. It is notorious that hydraulic stimulation techniques generate an impact or have a great relevance in the acceptance of the people surveyed, since it can be confused with hydraulic stimulation processes for shale gas extraction. Hydraulic stimulation for geothermal energy has been compared by the public with techniques implemented in hydrocarbon exploitation and associated with fracking (Biello 2013; Sun et al. 2017). This tendency can generate what is defined a controversy spillover, particularly a technology spillover in this case, as observed in the case of Switzerland (Cuppen et al. 2020). Therefore, in several regions of France, there are people who are opposed to hydraulic stimulation for geothermal energy since they point out the risk caused by technology used to facilitate water circulation in the rocks (Meng and Ashby 2014; Chavot et al. 2018). Even though there is a decrease in the acceptance of high enthalpy energy with the implementation of hydraulic stimulation, the acceptance is above $50 \%$, with a minimum of $62.82 \%$ in Canada and a maximum of $87.81 \%$ for Chile, indicating that for the public surveyed geothermal energy has fair acceptance.

\section{Conditions that should be satisfied to support a pilot geothermal project}

The implementation of a new energy technology, such as geothermal, is limited by community acceptance of its development. To narrow the gap between energy development and acceptance, several conditions must be met to enable communities to support pilot projects. In this case, the public surveyed has selected some aspects that they believe should be satisfied. The aspect that is highlighted as most important is the guarantee of environmental protection, which has been a common factor in the acceptance of geothermal studies (Carr-Cornish and Romanach 2014; Chavot et al. 2018), since the relationship between electrical energy and environmental impacts has resulted, in recent years, in the acceleration of climate change. Therefore, in the implementation of new technologies, a balance must be achieved between electrical production and the environment, and aspects such as the contamination of water resources must be minimized, while appropriate long-term monitoring must be ensured. The second aspect selected by the respondents reflects the need to guarantee the safety of the communities living 
close to the plant. In this regard, Bustaffa et al. (2020) described that, although geothermal energy is considered a clean and sustainable energy source, its use as for any other kind of energy generation, could produce an impact both on the environment and on the health of the communities living close to the power plants. Some geothermal plants, depending on their technology and on the geological characteristics of the reservoir, can generate gas emissions, such as hydrogen sulfide, hydrogen, ammonia, and volatile metals, among others. However, it is important to highlight that these emissions are generally lower than those generated by other energy sources (Bošnjaković et al. 2019), that they can be mitigated with appropriate technologies (Baldacci et al. 2005), and that binary power plants do not generate emissions (DiPippo 2012). Involving communities in geothermal projects can improve their position in the acceptance of geothermal energy. Although this survey has been carried out for a specific sector of the society, the answers are consistent with the results of other work focused on social acceptance (Carr-Cornish and Romanach 2014; Malo et al. 2015; Pellizzone et al. 2017). Therefore, environmental aspects, citizen participation, and the integration of social objectives should be a central focus in the implementation of geothermal energy.

\section{Conclusions}

An online survey conducted in Canada, Colombia, Chile, Belgium, and France is used as a tool to explore and characterize geothermal energy awareness and acceptance in a social segment primarily constituted by people with post-secondary education. Data were collected without any restriction to people who may answer. As a result, only respondents with high-level education were selected and considered for the analysis. The available participants for this research project were somewhat limited as the QuestionPro platform could be left open only for 3 months; reminders to invite the public to fill out the survey were regularly sent, but there were no tools to directly contact the respondents. Being an online survey, only the connected portion of the population could be reached. The acceptance and awareness of a technology can be based on the understanding of technical aspects or it can just be intuitive. In this survey both facets are considered and are not differentiated, since they both represent the knowledge of the respondents. The acceptance and awareness of geothermal energy have to be analyzed considering the current specific energy context of each country, as context changes may affect future perception.

Chile and Canada are the countries where the surveyed population shows a high degree of awareness of geothermal energy, while France and Belgium are characterized by a medium level and Colombia by a low one. These results are strongly dependent on the public segment selected for this survey, since, if the whole population is considered, a different scenario can be obtained, as shown by the Chilean National Energy Survey conducted in 2016 (Chilean Department of Energy 2017). France and Belgium have similar behavior and trends in percentages for all questions, while several differences can be observed when comparing North and South American countries. In general, the results of this survey show that there is a strong acceptance of electricity generation from deep geothermal resources, although this acceptance decreases when hydraulic stimulation is required. Nevertheless, a positive assessment is still observed in all countries. 
The positive acceptance of geothermal energy identified in the social segment surveyed in these five countries can contribute to unlocking new geothermal resources or to increasing their current utilization, depending on the current development at each site. However, since the results presented here do not fully characterize complete social acceptance given that the respondents are not representative of the whole society, site-specific outreach and education programs may be required for any new geothermal project. Awareness campaigns can be organized for different sectors of the society to provide basic guidelines to foster geothermal development, since geothermal energy is generally not widely known.

Based on this first experience, a new questionnaire involving different sectors of the society to evaluate the acceptance of geothermal energy can be envisioned. This future study can be conducted in a greater number of countries, limiting the responses to the identified target population. Countries belonging to the " $1 \mathrm{GW}$ geothermal country" club can be compared to those with incipient geothermal development. This kind of study can be used to establish guidelines to work with the communities, providing discussion opportunities for the growth of this energy source worldwide based on the experience of those sites where geothermal power generation has been successful.

\section{Supplementary Information}

The online version contains supplementary material available at https://doi.org/10.1186/s40517-021-00188-x.

Additional file 1. Appendix.

Abbreviations

EGS: Enhanced Geothermal Systems; IGCP: International Geoscience Programme; CEGA: Andean Geothermal Center of Excellence; BRGM: Bureau de Recherches Géologiques et Minières.

\section{Acknowledgements}

This work is part of the project "IGCP 636-Unifying international research forces to unlock and strengthen geothermal exploitation of Americas and Europe" developed between 2016 and 2020. The authors acknowledge the UNESCO (United Nations Educational, Scientific and Cultural Organization), IUGS (International Union of Geothermal Sciences) within the International Geoscience Programme (IGCP). We also acknowledge all the anonymous respondents who completed the survey in the five participating countries. Balzan-Alzate D. and Daniele L. acknowledge CEGA (fondap 15200001) support.

\section{Authors' contributions}

Conceptualization DBa, DBI, JL; methodology, JL; validation, JR; formal analysis, JL, JP, DM, MM; investigation, DBa; resources DBI, JR; data curation, ER, LD, CD, PG, TLB; writing —original draft preparation, $D B a$, JL; writing — review and editing DBa, DBI, JR, CD. All authors read and approved the final manuscript.

\section{Funding}

UNESCO (United Nations Educational, Scientific and Cultural Organization) and IUGS (International Union of Geological Sciences) within the International Geoscience Programme (IGCP) funded the QuestionPro license. The original questionnaire developed in Canada and which was adapted for all surveyed countries was established through a research project supported by the Fonds de recherche du Québec_-nature et technologies.

Availability of data and materials

The datasets used and/or analyzed during the current study are available from the corresponding author on reasonable request.

\section{Competing interests}

The authors declare that they have no competing interests.

\section{Author details}

${ }^{1}$ Departamento de Geología Y Centro de Excelencia en Geotermia de Los Andes (CEGA), FCFM, Universidad de Chile, Plaza Ercilla 803, Santiago, Chile. ${ }^{2}$ Universidad de Medellín, Programa de Ingeniería Ambiental, Carrera 87, N 30 65 Medellín, Colombia. ${ }^{3}$ Institut National de La Recherche Scientifique, 490 de la Couronne, Québec, QC G1K 9A9. Canada. ${ }^{4}$ Bureau de Recherches Géologiques Et Minières, 3 Avenue Claude Guillemin, 45100 Orléans, France. ${ }^{5}$ Université de Mons, Place du Parc 20, 7000 Mons, Belgique. ${ }^{6}$ Université de Rennes1, Rue du Thabor, 35000 Rennes, France. 
Received: 7 July 2020 Accepted: 29 January 2021

Published online: 02 March 2021

\section{References}

Alfaro C. Improvement of Perception of the Geothermal Energy as a Potential Source of Electrical Energy in Colombia, Country Update. In: Proceedings World Geothermal Congress, Melbourne. 2015; p. 15.

Allansdottir A, Pellizzone A, Sciullo A. Geothermal Energy and Public Engagement. In: Manzella A, Allansdottir A, Pellizzone A (eds) Geothermal Energy and Society. Lecture Notes in Energy. Cham: Springer. 2019; 67: 55-65.

Amin SB, Rahman S. Renewable energy practices in Bangladesh. Cham: Springer; 2019. p. 93-6.

Arango EE, Buitrago AJ, Cataldi R, Ferrara GC, Panichi C, Villegas VJ. Preliminary study on the Ruiz geothermal project (Colombia). Geothermics. 1970;2(1):43-56. https://doi.org/10.1016/0375-6505(70)90005-2.

Baldacci A, Mannari M, Sansone F. Greening of geothermal power: an innovative technology for abatement of hydrogen sulphide and mercury emission. In: Proceedings World Geothermal Congress Antalya, Turkey; 2005. p 24-29

Benighaus C, Bleicher A. Neither risky technology nor renewable electricity: contested frames in the development of geothermal energy in Germany. Energy Res Soc Sci. 2019;47:46-55. https://doi.org/10.1016/j.erss.2018.08.022.

Bertani R. Geothermal power generation in the world 2010-2014 update report. Geothermics. 2016;60:31-43. https://doi. org/10.1016/j.geothermics.2015.11.003.

Biello D. Fracking can be done safely, but will it be? Scientific America. Sustainability. 2013. https://www.scientificameri can.com/article/can-fracking-be-done-without-impacting-water/.

Bošnjaković M, Stojkov M, Jurjević M. Environmental impact of geothermal power plants. Technical Gazette. 2019;26:1515-1522. https://doi.org/10.17559/TV-20180829122640

Bouchot V, Sanjuan B, Traineau H, Guillou-Frottier L, Thinon I, Baltassat JM, Fabriol H, Bourgeois B, Lasne E. Assessment of the Bouillante Geothermal Field (Guadeloupe, French West Indies): Toward a Conceptual Model of the High Temperature Geothermal System. In: Proceedings World Geothermal Congress, Bali, Indonesia; 2010. p 8.

Bustaffa E, Cori L, Manzella A, Nuvolone D, Minichilli F, Bianchi F, Gorini F. The health of communities living in proximity of geothermal plants generating heat and electricity: a review. Sci Total Environ. 2020;706:135998.

Carr-Cornish S, Romanach L. Differences in public perceptions of geothermal energy technology in Australia. Energies. 2014;7:1555-75. https://doi.org/10.3390/en7031555.

Cataldi R. Social acceptance: a sine qua non for geothermal development in the 21st century. Bulletin d'Hydrogéologie. 1999:17:467-76.

CER Canada Energy Regulator. Canada's Adoption of Renewable Power Sources—Energy Market Analysis. 2020. https:// www.cer-rec.gc.ca/nrg/sttstc/lctrct/rprt/2017cnddptnrnwblpwr/hdr-eng.html.

Chavot P, Heimlich C, Masseran A, Serrano Y, Zoungrana J, Bodin C. Social shaping of deep geothermal projects in Alsace: politics, stakeholder attitudes and local democracy. Geothermal Energy. 2018. https://doi.org/10.1186/s4051 7-018-0111-6.

Chilean Department of Energy. Resultados Principales de Encuesta Nacional de Energía 2016. 2017. https://www.energ ia.gob.cl/noticias/nacional/encuesta-nacional-de-energia-2016.

Chilean Ministry of Energy. Mesa de geotermía: rol de la geotermía en el desarrollo de la matriz eléctrica chilena. Ministerio de Energía. 2018.

Colla M, loannou A, Falcone G. Critical review of competitiveness indicators for energy projects. Renew Sustain Energy Rev. 2020;125:109794. https://doi.org/10.1016/j.rser.2020.109794.

Colombian National Planning Department. Plan Nacional de Desarrollo 2018-2022: Pacto por Colombia, pacto por la equidad. 2019; p. 1660.

Cuenot N, Faucher JP, Fritsch D, Genter A, Szablinski D. The European EGS project at Soultz-sous-Forêts: From extensive exploration to power production. In: Proceedings IEEE Power and Energy Society General Meeting Conversion and Delivery of Electrical Energy in the 21st Century, Pittsburgh, Pennsylvania, 2008. p. 8.

Cuppen E, Ejderyan O, Pesch U, Spruit S, van de Grift E, Correljé A, Taebi B. When controversies cascade: Analysing the dynamics of public engagement and conflict in the Netherlands and Switzerland through "controversy spillover." Energy Res Soc Sci. 2020;68:101593. https://doi.org/10.1016/j.erss.2020.101593.

Devine-Wright P. Reconsidering public attitudes and public acceptance of renewable energy technologies: a critical review. Manchester Architecture Research Centre, University of Manchester. 2007. Working Paper 1.4.

Dickson MH, Fanelli M. What is geothermal energy? 2004. http://users.metu.edu.tr/mahmut/pete450/Dickson.pdf.

Dincer I. Renewable energy and sustainable development: a crucial review. Renew Sustain Energy Rev. 2000;4(2):157-75. https://doi.org/10.1016/S1364-0321(99)00011-8.

Dincer I, Acar C. A review on clean energy solutions for better sustainability. Int J Energy Res. 2015;39(5):585-606. https:// doi.org/10.1002/er.3329.

DiPippo R. Enhanced Geothermal Systems-Projects and Plants. Geothermal power plants: principles, applications, case studies and environmental impacts. Third Edition. Oxford: Butterworth-Heinemann, Elsevier; 2012.

Dowd AM, Boughen N, Ashworth P, Carr-Cornish S. Geothermal technology in Australia: investigating social acceptance. Energy Policy. 2011;39(10):6301-7. https://doi.org/10.1016/j.enpol.2011.07.029.

Dubois A, Holzer S, Xexakis G, Cousse J, Trutnevyte E. Informed citizen panels on the Swiss electricity mix: longer-term evolution of citizen preferences and affect in two cities. Energies. 2020;12:4231. https://doi.org/10.3390/en12224231

FEBEG Fédération Belge des Entreprises Électriques et Gazières. Annual Report FEBEG. 2020. https://www.febeg.be/sites/ default/files/febeg_annual_report_slide_deck_2019_fr_final.pdf.

Fung A. Varieties of participation in complex governance. Pub Adm Rev. 2006;66:66-75.https://doi.org/10.111 1/j.1540-6210.2006.00667.x. 
Genter A. Géothermie roches chaudes sèches. Le granite de Soultz-sous-Forêts (Bas-Rhin, France). Fracturation naturelle, altérations hydrothermales et interaction eau-roche. Bureau de recherches géologiques et minières (BRGM), Document No. 185, Ed. BRGM, Orléans, France. 1990; p. 201.

Goldstein B, Hiriart G, Tester J, Gutierrez-Negri L, Bertani R, Bromley C, Huenges E, Ragnarsson A, Mongillo M, Lund JW, Rybach L, Zui V, Muraoka H. Geothermal energy, nature, use, and expectations. In: Meyers RA, editor. Encyclopedia of sustainability science and technology. New York, NY: Springer; 2012. p. 4190-201.

Gómez T, Navarro D. Assessing the obstacles to the participation of renewable energy sources in the electricity market of Colombia. Renew Sustain Energy Rev. 2018;90:131-41. https://doi.org/10.1016/j.rser.2018.03.015.

Häring M, Schanz U, Ladner F, Dyer B. Characterisation of the Basel 1 enhanced geothermal system. Geothermics. 2008;37:469-95.

Hoes H, Petitclerc E, Declercq P.Y., Laenen B. 2013. Geothermal energy use, country update for Belgium. European Geothermal Congress, Pisa, Italy, 3-7 June. p 7.

Huenges E, Saada A, Brandt W, Moeck I, Holl HG, Zimmermann G, Blöcher G, Köhler S, Legarth B, Tischner T. Current status of the EGS gross schönebeck project: On the way to demonstrate sustainable brine production from deep sediments of the North German Basin. In: Proceedings GRC 2006 Annual Meeting: Geothermal Resources-Securing Our Energy Future, Transactions_-Geothermal Resources Council. 2006. 30: 341-345.

IEA, International Energy Agency. Technology Roadmap-Geothermal Heat and Power. IEA Publications, Paris, France. 2011.

IEA, International Energy Agency. Energy Policies of IEA Countries, Belgium: 2016 review. IEA Publications. 2016; p. 178. IEA, International Energy Agency. Energy Policies of IEA Countries, France, Review. IEA Publications. 2017; p. 211.

IPCC, Intergovernmental Panel on Climate Change. Renewable Energy Sources and Climate Change Mitigation. Special Report of the Intergovernmental Panel on Climate Change. Cambridge: Cambridge University Press. 2012; p. 1088

IRENA. Renewable capacity statistics. International Renewable Energy Agency, Abu Dhabi. 2019. p. 60.

IRENA. Renewable power generation costs in 2019. International Renewable Energy Agency, Abu Dhabi. 2020. p. 144.

Jasanoff S. States of Knowledge: The Co-Production of Science and the Social Order. Routledge 2004; p. 317.

Jessop AM, Ghomshei MM, Drury MJ. Geothermal energy in Canada. Geothermics. 1991;20(5-6):369-85. https://doi. org/10.1016/0375-6505(91)90027-S.

Jorquera C. Primera planta geotérmica de América del sur - Cerro Pabellón de 48 MW inicia operación. Piensa en geotermia. 2017. http://www.piensageotermia.com/primera-planta-geotermica-de-america-del-sur-cerro-pabel Ion-de-48-mw-inicia-operacion. Accessed 3 April 2019.

Jugend D, De Camargo Fiorini P, Armellini F, Ferrari AG. Public support for innovation: a systematic review of the literature and implications for open innovation. Technol Forecast Soc Chang. 2020;156:119985.

Kaieda H. Ogachi EGS Reservoir Analysis Central Research Institute of Electric Power Industry, Abiko, Chiba, Japón. GRC Trans. 2012;36:487-92.

Karmaker AM, Rahman M, Hossain A, Ahmed R. Exploration and corrective measures of greenhouse gas emission from fossil fuel power stations for Bangladesh. J Clean Prod. 2020. https://doi.org/10.1016/j.jclepro.2019.118645.

Kępińska B, Kasztelewicz A. Public perception of geothermal energy in selected European countries. In: Proceedings World Geothermal Congress, Melbourne, Australia. 2015; p. 12.

King JP, Reid PW, Bendall B. Progress at the Paralana EGS Project in South Australia. In: Proceedings Australian Geothermal Energy. 2009. p. 74-76.

Lagrou D, Petitclerc E, Hoes H, Dupont N, Laenen B. Geothermal energy use, country update for Belgium. 2019. In: Proceedings European Geothermal Congress, Den Haag, The Netherland. 2019; p. 6.

Lahsen A, F Sepúlveda, Rojas J, Palacios C. Present Status of Geothermal Exploration in Chile. In: Proceedings World Geothermal Congress, Melbourne, Australia; 2015. p. 8.

Lennon B, Dunphy NP, Sanvicente E. Community acceptability and the energy transition: a citizens' perspective. Energy Sustain Soc. 2019;9:35. https://doi.org/10.1186/s13705-019-0218-z.

Lins C, Williamson LE, Leitner S, Teske S. The first decade: 2004-2014: 10 years of renewable energy progress. Renew Energy Policy Network for the 21st Century. 2014. ISBN: 978-3-9815934-4-0. http://hdl.handle.net/10453/117208.

Loveless S, Pluymaekers M, Lagrou D, De Boever E, Doornenbal H, Laenen B. Mapping the geothermal potential of fault zones in the Belgium-Netherlands border region. European Geosciences Union General Assembly. Energy Procedia. 2014;59:351-8. https://doi.org/10.1016/j.egypro.2014.10.388.

Majorowicz J, Grasby S. Deep geothermal energy in Canadian sedimentary basins Vs. fossils based energy we try to replace—exergy [KJ/KG] compared. Renew Energy. 2019;141:259-77. https://doi.org/10.1016/j.renene.2019.03.098.

Malo M, Moutemet JP, Bédard K, Raymond J. Public Awareness and Opinion on Deep Geothermal Energy in the Context of Shale Gas Exploration in the Province of Quebec, Canada. In: Proceedings World Geothermal Congress, Melbourne, Australia. 2015. p. 8.

Mejia E, Rayo L, Méndez J, Echeverri J. Geothermal Development in Colombia. In: Proceeding Short Course VI on Utilization of Low- and Medium-Enthalpy Geothermal Resources and Financial Aspects of Utilization, La Geo, El Salvador 2014. p. 7.

Meller C, Schill E, Bremer J, Kolditz O, Bleicher A, Benighaus C, Chavot P, Gros M, Pellizzone A, Renn O, Schilling F, Kohl T. Acceptability of geothermal installations: a geoethical concept for GeoLaB. Geothermics. 2018;75:133-45. https:// doi.org/10.1016/j.geothermics.2017.07.008.

Meng Q, Ashby S. Distance: a critical aspect for environmental impact assessment of hydraulic fracking. Extract Ind Soc. 2014;1(2):124-6.

Mondani F, Aleagha S, Khoramivafa M, Ghobadi R. Evaluation of greenhouse gases emission based on energy consumption in wheat Agroecosystems. Energy Rep. 2017;3:37-45. https://doi.org/10.1016/j.egyr.2017.01.002.

Monsalve ML, Rodriguez GI, Mendez RA, Bernal NF. Geology of the Well Nereidas 1, Nevado Del Ruiz Volcano, Colombia. Geother Res Council Trans. 1998;22:263-8.

Morata D. ¿Chile: un país geotérmico en un futuro inmediato? Anales. 2004;5:71-86.

Moreno-Rendón DA, López-Sánchez J, Blessent D. Geothermal energy in Colombia as of 2018. Ingenieria y universidad: engineering for development. 2020. https://doi.org/10.11144/Javeriana.iyu24.geic. 
Mouchot J, Genter A, Cuenot N, Scheiber J, Seibel O, Bosia C, Ravier G. First Year of Operation from EGS geothermal plants in Alsace, France: Scaling Issues. In: Proceedings 43rd Workshop on Geothermal Reservoir Engineering, Stanford University, Stanford, California. 2018; p 12.

National Research Council. Electricity from renewable resources: status, prospects, and impediments. Washington, DC: The National Academies Press. 2010. https://doi.org/https://doi.org/10.17226/12619.

O'Ryan R, Nasirov S, Álvarez-Espinosa A. Renewable energy expansion in the Chilean power market: a dynamic general equilibrium approach to determine CO2 emission baselines. J Clean Prod. 2020. https://doi.org/10.1016/j.jclepro.2019.119645.

Olasolo P, Juaréz MC, Morales MP, D'Amico S, Liarte IA. Enhanced geothermal systems (EGS): a review. Renew Sustain Energy Rev. 2016;56:133-44. https://doi.org/10.1016/j.rser.2015.11.031.

Owusu PA, Asumadu-Sarkodie S. A review of renewable energy sources, sustainability issues and climate change mitigation. Cogent Eng. 2016;3(1167990):14. https://doi.org/10.1080/23311916.2016.1167990.

Palacio-Villa MA, Blessent D, López-Sánchez J, Moreno D. Sistemas geotérmicos mejorados: revisión y análisis de casos de estudio. Boletín de Geología. 2020;42(1):101-18. https://doi.org/10.18273/revbol.v42n1-2020006.

Pellizzone A, Allansdottir A, De Franco R, Muttoni G, Manzella A. Exploring public engagement with geothermal energy in southern Italy: a case study. Energy Policy. 2015;85:1-11.

Pellizzone A, Allansdottir A, De Franco R, Muttoni G, Manzella A. Geothermal energy and the public: a case study on deliberative citizens' engagement in central Italy. Energy Policy. 2017;101:561-70. https://doi.org/10.1016/j.enpol .2016.11.013.

Procesi M. Geothermal potential evaluation for Northern Chile and suggestions for new energy plans. Energies. 2014:7:5444-59.

Raymond J, Malo M, Tanguay D, Grasby SE, Bakhteyar F. Direct utilization of geothermal energy from coast to coast: a review of current applications and research in Canada. In: Proceedings of the World Geothermal Congress, Melbourne, Australia. 2015; p 10

Reiter M, Weidman C, Edwards CL, Hartman H. Subsurface Temperature Data in Jemez Mountains, New Mexico. Socorro, NM: New Mexico Bureau of Mines and Mineral Resources. Report No. Circular 151. 1976.

Reith S, Kölbel T, Schlagermann P, Pellizzone A, Allansdottir A. Public acceptance of geothermal electricity production. GEOELEC 2013; Report. p. 41.

Richter A. Having been sold to Ormat, the Bouillante geothermal power plant in Guadeloupe in the Caribbean could be expanded by $30 \mathrm{MW}$ for a total capacity of $45 \mathrm{MW}$ by 2021. ThinkGeoEnergy. 2016. http://www.thinkgeoenergy. com/plans-for-30-mw-expansion-for-guadeloupe-geothermal-plant/. Accessed 3 April 2019.

Richter A. Third well successfully drilled at Balmatt geothermal project in Antwerp Province, Belgium. ThinkGeoEnergy. 2018. https://www.thinkgeoenergy.com/third-well-successfully-drilled-at-balmatt-geothermal-project-in-antwe rp-province-belgium/. Accessed 7 April 2019.

ScharffC. Un nouveau projet géothermique lancé en pleine ville de Mons. L'Echo. 2019. https://www.lecho.be/dossier/pmewallonie/un-nouveau-projet-geothermique-lance-en-pleine-ville-de-mons/10098823.html. Accessed 7 April 2019.

Sovacool BK, Ryan SE, Stern PC, Janda K, Rochlin G, Spreng D, Pasqualetti MJ, Wilhite H, Lutzenhiser L. Integrating social science in energy research. Energy Res Soc Sci. 2015;6:95-9. https://doi.org/10.1016/j.erss.2014.12.005.

Stauffacher M, Muggli N, Scolobig A, Moser C. Framing deep geothermal energy in mass media: the case of Switzerland. Technol Forecast Soc Chang. 2015;98:60-70.

Sun Z, Zang X, Xu Y, Yao J, Wang H, Lv S, Sun Z, Huang Y, Cai M, Huang X. Numerical simulation of the heat extraction in EGS with thermal-hydraulic-mechanical coupling method based on discrete fractures model. Energy. 2017;120:2033. https://doi.org/10.1016/j.energy.2016.10.046.

UN, United Nations. About the Sustainable Development Goals. 2015. https:/www.un.org/sustainabledevelopment/ sustainable-development-goals/

Vargas S. Understanding social acceptance of geothermal energy: case of study for Araucanía region, Chile. Geothermics. 2018;72:138-44.

Vargas S, Martinez-Reyes A, Ejderyan O. Factors and dynamics of the social perception of geothermal energy: Case study of the Tolhuaca exploration project in Chile. Geothermics. 2020;88:101907.

Vernier R, Laplaige P, Desplan A, Boissavy C. France Country Update. In: Proceedings World Geothermal Congress, Melbourne, Australia; 2015. p. 8.

Volken S, Xexakis G, Trutnevyte E. Perspectives of informed citizen panel on low-carbon electricity portfolios in Switzerland and longer-term evaluation of informational materials. Environ Sci Technol. 2018;52(20):11478-89. https://doi. org/10.1021/acs.est.8b01265.

von Wirth T, Gislason L, Seidl R. Distributed energy systems on a neighborhood scale: reviewing drivers of and barriers to social acceptance. Renew Sustain Energy Rev. 2018;82:2618-28. https://doi.org/10.1016/j.rser.2017.09.086.

Wadström C, Wittberg E, Salah G, Jayasekera R. Role of renewable energy on industrial output in Canada. Energy Econ. 2019;81:626-38.

Watanabe N, Blöcher G, Cacace M, Held S, Kohl T. Geoenergy Modeling III: enhanced geothermal systems. Berlin: Springer; 2016. p. 119.

WMO, World Meteorological Organization. Greenhouse gas concentrations in atmosphere reach yet another high. 2019. https://public.wmo.int/en/media/press-release/greenhouse-gas-concentrations-atmosphere-reach-yet-another-high.

Wüstenhagen R, Wolsink M, Bürer MJ. Social acceptance of renewable energy innovation: an introduction to the concept. Energy Policy. 2007;35(5):2683-91.

Wyss R, Rybach L. Developing deep geothermal resources in Switzerland. In: Proceedings World Geothermal Congress, Bali, Indonesia; 2010. p. 4.

Yasukawa K, Kubota H, Soma N, Noda T. Integration of natural and social environment in the implementation of geothermal projects. Geothermics. 2018;73(2018):111-23.

\section{Publisher's Note}

Springer Nature remains neutral with regard to jurisdictional claims in published maps and institutional affiliations. 